Haya: The Saudi Journal of Life Sciences

Abbreviated Key Title: Haya Saudi J Life Sci

ISSN 2415-623X (Print) |ISSN 2415-6221 (Online)

Scholars Middle East Publishers, Dubai, United Arab Emirates

Journal homepage: https://saudijournals.com

Review Article

\title{
Biodiversity and its Conservation in Balochistan, Pakistan
}

\author{
Sadia Hassan Sherani ${ }^{*}$ \\ Department of Environmental Sciences, Sardar Bahadur Khan Women's University Quetta, Balochistan, Pakistan
}

\begin{tabular}{lr}
\hline DOI: $10.36348 /$ sjls.2020.v05i11.004 & $\mid$ Received: $12.11 .2020 \mid$ Accepted: $23.11 .2020 \mid$ Published: 30.11 .2020 \\
*Corresponding author: Sadia Hassan Sherani & Email: sadiasherani.333@gmail.com
\end{tabular}

Abstract

The present review paper highlights the condition of biodiversity and its conservation in Balochistan, Pakistan. Balochistan is a province of Pakistan that is supported by a great variety of wild flora and fauna. Attractive landscapes, scenic beaches and magnificent forests of the province offers home to various kinds of idiosyncratic species of the world. Moreover, to enhance and maintain the scenic view of province, different innovative practices are needed to conserve and protect the biodiversity from future threats. Furthermore, this paper sensitizes the readers about the consequences of improper conservation practices that can lead towards future destruction. It also throws light on the fact that it is necessary to protect and conserve the biological diversity in appropriate manner to minimize the overall impacts towards biodiversity and to protect the biodiversity from future vanishing threats.

Keywords: Awareness, Efficient practices, Threats, Protection, Balochistan.

Copyright (C) 2020 The Author(s): This is an open-access article distributed under the terms of the Creative Commons Attribution 4.0 International License (CC BY-NC 4.0) which permits unrestricted use, distribution, and reproduction in any medium for non-commercial use provided the original author and source are credited.

\section{INTRODUCTION}

In the simplest way, biodiversity is the variety of plant and animal life on earth [1]. It is a key resource as it provides both goods and services to society. Globally forests are considered as important because it play a vital role in the protection and conservation of biodiversity. Forests support the biodiversity in many ways and play a dynamic role in protecting the fragile mountain ecosystem and maintaining diverse and complex ecosystems [2,3]. Biodiversity is essential for human survival and economic well-being and for the ecosystem structure, functioning and stability [4-6]. Additionally, poverty, population pressure, pollution, habitat destruction, habitat fragmentation, and agricultural expansion have been suggested as major threats towards biodiversity [7-10].

Balochistan is located in south-western part of Pakistan. It has total land area of $347,190 \mathrm{~km}^{2}$ and it covers $44 \%$ of Pakistan's total land cover which makes it Pakistan's largest province in terms of area. Balochistan is blessed by a number of resources that's why it is considered as one of the most important wildlife region of Pakistan (Contains a large number of species) [11, 12]. Balochistan is rich in biodiversity and huge number of species is present here, that's why considered as the traditional zone between the oriental and palaearctic zoogeographical regions. Furthermore, from thousands of years people of Balochistan sustained themselves on plants and animal species that are present around them. Settlements have started in the province after agriculture initiation which made urban life possible afterwards. All the ecosystem of the province are used by the people of Balochistan for different purposes such as, trees/shrubs used as a fuel, herbs used as a medicine etc [13].

The distribution of plants and animals species depends on the geographical region. The number of well-known plant species in Balochistan is at least 1,750 [14]. And the number of well-known animal species in Balochistan includes; 71 species of mammals, 356 species of birds, 94 species of reptiles, 8 species of amphibians and 61 species of fresh water fishes [15]. Balochistan to the west lies with Seistan Desert Basin, to the east lies with Cholistan and Thar Deserts, to the north lies with some mountain ranges including Himalayas and to the south lies with Arabian Sea. Consequently, variations in climate and physical features have produced diverse ecosystems, habitats and landscapes in Balochistan [11, 16-18].

\section{Forest types in Balochistan}

The major types of forests in Balochistan are coniferous forest, scrub forest, sub-tropical desert, riverian forest and mangrove forest.

1. Coniferous forests: Coniferous forests are cone bearing trees, having needle-like leaves and remains green throughout the year and it occur at 
elevations of 1,500 to $3,500 \mathrm{~m}$. In Balochistan Coniferous forests are further divided into two types that are Dry Juniper forest (Juniperus excelsa) and Chilghoza forest (Pinus gerardiana). Juniper forest is found in Ziarat and Zarghoon hills, ranging from 1,980 to 3,350 $\mathrm{m}$ in elevation. Juniper forest is dominant in Balochistan and is considered as one of the world oldest forests. Along with this, it is also considered as the Asia's largest forest that covers about 141,000 ha area. On the other hand, Chilghoza forest is found in Sulaiman Mountains in the Sherani tribal area (Sherani district), ranging from 2,700 to 3,400 $\mathrm{m}$ in elevation. The main areas of Chilghoza forest are found at Torghar, Shinghar, Kaisaghar and Takht-e-Sulaiman [11].

2. Scrub forests: Scrub forests occur at elevations of 500 to $1,500 \mathrm{~m}$. They provide protection to agricultural land by controlling soil erosion and intensity of flash floods. Scrub forests in Balochistan are further divided into three types which include; Balochistan Dry Temperate Scrub forest (Steppe), Dry Subtropical Broad-leaved forest and Tropical Thorn forest. Balochistan Dry Temperate Scrub forest is found in Quetta, Qilabdullah, Pishin, Mastung, Kalat, and Qilasaifullah. Dry Subtropical Broad Leaved forest is found in Sulaiman Mountainous Region and Tropical Thorn forest is found in Sibi plains and Nok Kundi [11].

3. Subtropical desert: Sub tropical desert are divided into to three types includes; Haloxylon persicum, H.Salicornicum rhazya and salt flats. Haloxylon persicum is found in Kharan and Chagai districts, ranging in elevations from 600 to $920 \mathrm{~m}$. H.salicornicum-rhazya is also found in Kharan and Chagai districts, ranging in elevations from 480 to $1,220 \mathrm{~m}$ and Salt flats is found in dry salt lakes such as Hamun-e-Mashkel and Hamun-e-Lora in Kharan and Chagai districts, ranging in elevations from 610 to $860 \mathrm{~m}$ [11].

4. Riverian and mangrove forests: Riverian forest is found in Sibi and Lasbela and mangrove forest is found in Gwadar and Lasbela along the cost. Common trees of that area are Prosopis cineraria which are occurred naturally and introduced trees are Salix spp, Morusalba, Pinuseldarica etc [11].

\section{Wetlands in Balochistan}

Wetland is the zone between terrestrial and aquatic ecosystem. In Balochistan, wetlands attract a variety of species such as grebes, herons, ducks, swans etc. Wetlands in Balochistan are found in Chagai district (Zanginawar lake), Quetta (Spin karez \&Hanna lake), and Lasbela district (Siranda lake).These wetlands support a variety of plant and animal species which make them rich in biodiversity [11].
Migratory birds, mammals and reptiles in Balochistan

Several species migrate to province, including grey herons, mallards, houbara bustard, falcons and Siberian cranes. Migratory birds arrive in the areas of Quetta, Kharan, Zhob, Nuskhi, Chagai, Lasbela, Loralai and Hab district. However, now these regions are experiencing decline in the number of migratory birds due to the excessive hunting pressure and climatic changes. In the province, several species of mammals are present in a wide range. According to IUCN [13] red list of threatened animals, in Balochistan four species of mammals are at a great risk, among which two are critically endangered mammal including chiltan wild goat and Balochistan black bear and the two are endangered mammal including afghan urial and straight horned markhor. And in recent decades two species of mammal have become extinct from Balochistan, including Indian wild ass and the Asiatic cheetah [Government of Balochistan and IUCN Pakistan [11]. In Balochistan, Chagai desert is dominated by a variety of reptiles including Lumsdeni gecko, short-toed sand swimmer, mountain dwarf gecko, Caspian desert lacerta, dark headed gamma snake, spiny tailed lizard, sharp tailed spider gecko and many others [11, 19-21].

\section{Crop and livestock biodiversity in Balochistan}

Diverse climate and soil structure facilitates the cultivation of different crops in the province. Wide ranges of crops are present in the province that contributes to the diversity of agriculture. Furthermore, more than hundred un-described varieties of crop are also grown in this region. Along with this, well-known breeds or varieties of livestock are also present in Balochistan. There are six main breeds of sheep, four main breeds of goat and three main breeds of cattle. Moreover, in this region the camel commonly found is known as the Arabian one-humped camel [11].

\section{Protected areas in Balochistan}

In Balochistan protected areas consists of forests, parks, wildlife sanctuaries and game reserves. The Balochistan forest department holds about $3 \%$ of the land that includes; forests, wildlife areas, rangelands and many deforested lands. Furthermore, forest department gives legal protection to 22 threatened tree species. Balochistan wildlife act of 1974 provides establishment of national parks, wildlife sanctuaries and game reserves. In Balochistan there is two national parks (Hazarganji-Chiltan and Hingol), 14 wildlife sanctuaries (Khurkhera, Buzi Makola, Chorani, Kachau, Shaahan, Raghai Rakshan, Kolwa Kap, Maslakh, Ziarat, Sasnamana, Gut, Koh-e-Gishk, RasKoh and Chhapar Kohan), 8 game reserves (Dureji, Band Khushdil Khan, Zangi Nawar, Gogi, Wam, Zawakhan, Kambran and Duzdara/Koh-e-Surko), 5 private game reserves (Hapursi, Tobati, Dher, Gaj Kolachi/Kanjoo and Lohindo), and 1 community conservation area (Torghar). The total protected area is about 1.829 
million hectares, which constitutes $5.3 \%$ of the province's geographical area $[11,13,22,23]$.

\section{Environmental degradation in Balochistan due to improper management practices}

Biological diversity in province is facing threats due to poor management practices. Number of people and livestock has increased in province that's why they are exerting heavy pressure on the limited natural resources. Moreover, wild life population has declined in the province and some species are classified as endangered. Forests are degraded due to cutting of trees for different purposes such as for fuel, timber etc. Additionally, wetlands are threatened from siltation, encroachment, pollution and human pressure [11]. Moreover, unsustainable use of resources and lack of proper management system is responsible for the environmental degradation and extinction of idealistic species.

\section{Major threats towards biodiversity in Balochistan \\ In Balochistan, different factors are} responsible for the degradation of biological diversity. Human activities are exerting pressure on biological diversity in both direct and indirect ways. In this province, no proper measures are being taken in order to conserve or protect unique biodiversity. Illegal hunting, poaching and trade are the main issues that are leading towards species extinction. Environment violating factors such as population explosion, deforestation, over extraction of resources, habitat fragmentation/degradation, climate change, global warming and pollution play a significant role in disruption of unique ecosystems and also putting lives of valuable and rare species in danger [12, 24, 21, 25].

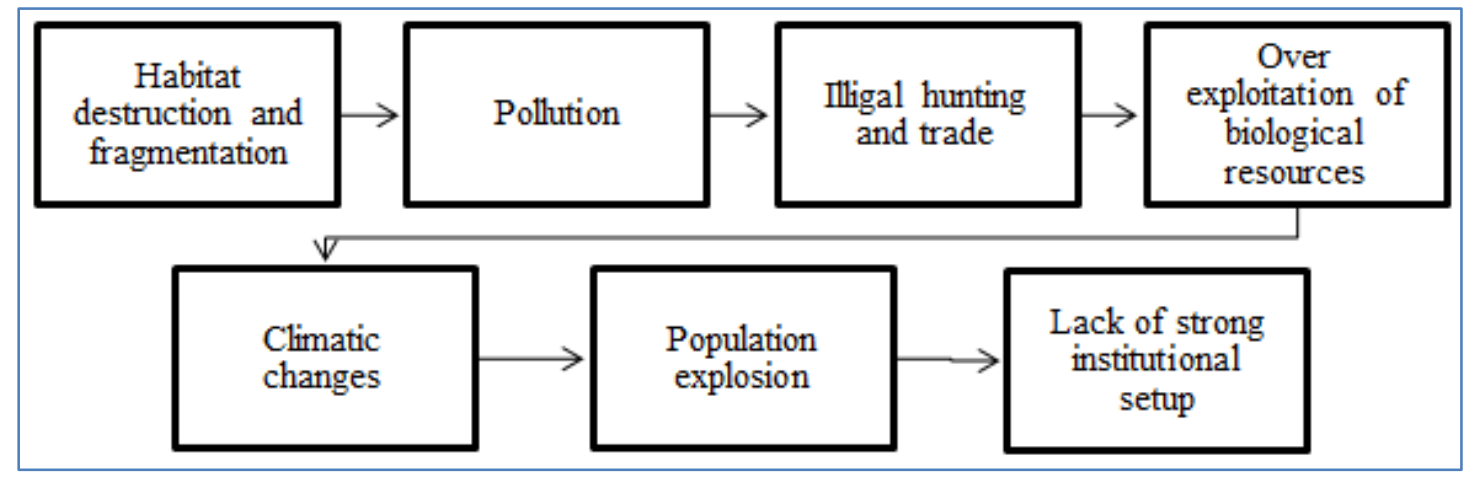

Fig-1: Threats to biodiversity

\section{Policy, legislation and institutions responsible for the management}

Forest and wildlife sector is responsible for the management and enforcement of legislation but due to Lack of institutional setup and proper authorities it will lead to poor management and legislation. In Balochistan, there is no effective mechanism and procedure to put the policy into action. Current laws and regulations are not flexible to conserve the biological diversity in proper manner. Improper practices for the biodiversity conservation or management will always lead to dangerous situations that's why we need proper polices, rules and regulation for the protection of biological diversity in proper manner. Hence, Balochistan needs its own concrete polices for forests and biodiversity in order to conserve and protect them $[10,11]$. In Balochistan there is no research institution which focuses on nature conservation. Furthermore, two international conservation organizations (WWF and IUCN) are working in the province for the proper management of resources and biological diversity. The forestry sector in Balochistan is taking some actions in order to save or protect forests. Hence, to conserve the biodiversity and to increase their contribution towards economy through ecotourism in province some non-commercial forests may be designated as parks and protected areas [11].
Proper conservation practices are required to protect the biodiversity from future vanishing threats

- The most important measure must launch by the government and conservation organizations are extensive province wide education, awareness and communication programmes. Comprehensive programme must be launched in the whole province, in order to target all the sectors of population both rural and urban areas. Gives information to every individual that, what is biodiversity and why it is important to all of us, and what we can do to protect, preserve and conserve it.

- Create awareness among the local communities or initiate public awareness campaigns in and around known sites. Awareness is very substantial for the conservation and protection of biological diversity in the province. So, Must be aware the people about the importance of natural resources to save the resources for present as well as for future generations.

- Strong institutional setup is required in the whole province for the proper protection of unique and valuable ecosystem.

- Policy makers, conservation activists, environmentalists, forest and wildlife departments, 
governmental and non-governmental institutes should work together along with the local communities for the conservation of biodiversity, protected areas and their surrounding landscapes.

- Protect the current habitats of unique species and declared some sites as protected areas. And improve the management in key protected areas. Develop monitoring methods and then monitor key protected areas.

- Prohibit deforestation and reduce or minimize the level of pollution because it is the prime cause for decrease in population of different species.

- Prohibit illegal hunting and poaching. And restrict direct exploitation that is due to overhunting, poaching, poisoning, and trapping.

- Conduct surveys and different programs to increase the knowledge about the current situation of species. Furthermore, promote the local participation towards different conservation practices.

- Promoting cooperative research efforts between conservationists and environmentalists and conducting province wide environmental education activities among communities and stakeholders.

- The existence environmental laws should be in action and strictly followed by everyone.

- Government of Balochistan should make their own laws and policies for the proper protection of their valuable biological diversity.

- Conservation techniques (In-situ and Ex-situ) must be adopted by the governmental organizations in proper manner to protect the unique biodiversity in the province.

\section{Biodiversity conservation techniques}

In province biodiversity can be protected or conserved by adopting two techniques that are in-situ and ex-situ conservation technique [7, 27].

1. In-situ conservation technique: It is the conservation of different species in their natual habitat, also known as on-site conservation technique. It is cost effective and very convenient method. Large numbers of species are conserved within their natural habitat. It includes protected areas such as national parks, wildlife sanacturaies, biosphere reserves etc.

2. Ex-situ conservation technique: It is the conservation of different species outside their natural habitat, also known as off-site conservation technique. Artifical ecosystem are designed for the breeding and maintenance of endangerd species. In this conservation method the species breed in capativity can be re-introduced in the wild. It includes seed bank, gene bank, botinical garden, zoological parks, aquaria, arboreta etc.

The main aim of these both techniques are to recover and maintained the population of different species $[11,26]$. Proper conservation practices are needed in the whole province to improve the status of biodiversity. Hence, government of balochistan should take some serious actions by adopting and launching these two techniques in proper manner to protect eceonomically important species and unique ecosystems.

\section{CONCLUSION}

Balochistan is supported by a variety of biological diversity. It is a natural habitat for a variety of unique flora and fauna. In this province, beautiful scenic places offers home to various idiosyncratic species of the world that's why biodiversity of the province needs proper protection and conservation and this can be only possible by the cooperation of all organizations either private or governmental along with the participation of local community. Awareness is the key step towards sustainable use of biological resources. If these biological resources will be used in sustainable manner then they would not only be enjoyed by the present generation but also by the future generations. Hence, humans must live in harmony with nature and they should not harm the biological diversity. Every organism on earth has equal right to exist, whether it is valuable to humans or not.

"We should preserve every scrap of biodiversity as priceless while we learn to use it and come to understand what it means to humanity" (E.O. Wilson).

\section{RECOMMENDATION}

For enhancing and upgrading the conservation practices of biodiversity, one of the influential activities can be the conduction of effective researches. Such detailed and meticulous researches should be conducted which can identify the potential threats that are being faced by the biodiversity in Balochistan. This will not only help in attaining rational understanding of the issues prevailing in biodiversity's habitats but also assist to tackle such issues in an effective manner. Additionally, various governmental and nongovernmental institutes should support such works and initiatives for improving the status of biodiversity.

\section{ABBREVIATIONS}

GOB: Government of Balochistan; WWF: World Wide Fund for Nature; IUCN: International Union for Conservation of Nature; km: kilometre

\section{REFERENCES}

1. Corker, B. (2003). Biodiversity and conservation. Available http://www.countrysideinfo.co.uk/biodvy4.htm.

2. Rana, S., Bargali, K., \& Bargali, S. S. (2015). Assessment of plant diversity, regeneration status, biomass and carbon stock in a Central Himalayan cypress forest. International Journal of Biodiversity and Conservation, 7(6), 321-329. 
3. Himani, K., Kiran, B., Bargali, S. S., \& Rawat, Y. S. (2017). Plant diversity, regeneration status and standing biomass under varied degree of disturbances in temperate mixed oak-conifer forest, Kumaun Himalaya. International Journal of Ecology and Environmental Sciences, 43(4), 331345.

4. Singh, J. S. (2002). The biodiversity crisis: a multifaceted review. Current Science, 82(6), 638647.

5. Bargali, S. S., Singh, S. P., \& Singh, R. P. (1992). Structure and function of an age series of eucalypt plantations in Central Himalaya. I. Dry matter dynamics. Annals of Botany, 69(5), 405-411.

6. Bargali, S. S., Singh, R. P., \& Singh, S. P. (1992). Structure and function of an age series of eucalypt plantations in Central Himalaya, II. Nutrient dynamics. Annals of Botany, 69(5), 413-421.

7. Davidar, P., Sahoo, S., Mammen, P. C., Acharya, P., Puyravaud, J. P., Arjunan, M., ... \& Roessingh, K. (2010). Assessing the extent and causes of forest degradation in India: Where do we stand?. Biological Conservation, 143(12), $2937-$ 2944.

8. Baboo, B., Sagar, R., Bargali, S. S., \& Verma, H. (2017). Tree species composition, regeneration and diversity of an Indian dry tropical forest protected area. Tropical Ecology, 58(2), 409-423.

9. Bargali, K., Joshi, B., Bargali, S. S., \& Singh, S. P. (2014). Diversity within oaks. International oaks, 25, 57-70.

10. Bargali, K., Joshi, B., Bargali, S. S., \& Singh, S. P. (2015). Oaks and the biodiversity they sustain. International Oaks, 26, 65-76.

11. Government of Balochistan and IUCN Pakistan. (2000). Balochistan Conservation Strategy, IUCN Pakistan: 74-95.

12. Javed, M. (2019). Endangered species of Balochistan. Published in Voice of Balochistan. Available at: https:/voiceofbalochistan.pk/opinionsand-articles/social-development/endangeredspecies-of-balochistan/.

13. IUCN. (1997). Protected areas management project. 6 vols. Karachi: IUCN and WWF Pakistan.

14. Rafiq. (1965).Vegetation types of Quetta region: (unpublished manuscript).
15. Roberts, T.J. (1997). Mammals of Pakistan. Karachi: Oxford university press.

16. Musakhel, M.Y. (2008). Biodiversity information of Balochistan, Pakistan. Available at: https://www.researchgate.net/publication/31894736 5-biodiversity-information-of-balochistan.

17. Bibi, T. (2015). The endemic medicinal plants of northern Balochistan, Pakistan and their uses in traditional medicine. Journal of Ethnopharmacology 173: 1-10.

18. Qureshi, R. (2012). Medicinal flora of Hingol national park, Balochistan. Pakistan journal of botany, 44(2): 725-732.

19. Ghalib, S. (1979). A checklist of the reptiles of Pakistan. Records of the zoological survey department: VIII, Nos. $1 \& 2$.

20. Syed, A. (2007). Current status of the mammals of the Balochistan. Pakistan journal of Zoology, 39(2): 117-122.

21. Tareen, G.K. (2017). Balochistan's wild life. Published in dawn newspaper. Available at: https://www.dawn.com/news/1368044/ balochistans-wildlife.

22. Groombridge, B. (1998). Balochistan province of Pakistan. A preliminary environmental profile. Karachi: IUCN.

23. WWF-Pakistan. (1998). Hazarganji Chiltan National Park Management Plan, Quetta: WWF.

24. Top major threats towards biodiversity, published in bio Explorer; Ecology-Environment, published at $31^{\text {st }}$ March, 2020. Available at: https://www.bioexprorer.net/threats-to-biodiversity.

25. Rawat, U. S., \& Agarwal, N. K. (2015). Biodiversity: concept, threats and conservation. Environment Conservation Journal, 16(3), 19-28.

26. Ramya, A.R. (2014). A review on in-situ and exsitu conservation strategies. International Journal of Applied Biology and Pharmaceutical Technology 5(1).

27. DeGeorges, P.A., \& Reilly, B. K. (2009). The realities of community based natural resource management and biodiversity conservation in SubSaharan Africa. Sustainability (Published by MDPI), 1(3): 734-788. 